\title{
Berlin universities head off major new cuts in funding
}

Munich. Fears of a massive cut in funds for Berlin's three universities, which threatened to close entire faculties, slash student numbers and cut staff numbers by about a thousand over the next eight years, have been partially averted following prolonged negotiations with the city's political representatives.

Cuts will still have to be made. But they will not be as extensive as the DM135 million (US\$85 million) proposed by the city's finance ministry in March. The universities are now working with politicians to identify how much money could reasonably be saved and exactly where the savings could be made.

But it will still not be easy to reach agreement on where the extra cuts should fall, even though this has to be achieved by the end

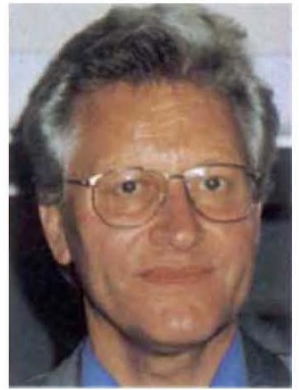

Erhardt: sees problems ahead. of the year in order for the budget for the two years 1995 and 1996 to become effective.

The three universities - The Free University and the Technical University in the west, and the east's Humboldt University -. each fear that any further cuts, coming directly on top of severe restructuring agreed last year, could cause significant damage.

All three agree that rationalization was essential after German unification in 1990. The Free University, for example, was established in 1949 to replace the Humboldt University, and there is now an expensive overlap of many faculties and departments in the university system of the reunited city.

Reunification also meant the loss of Berlin's generous subsidy from Bonn - for many decades, the West German government had supported the many cultural activities of the isolated city in order to make it a flagship of democracy.

At the end of last year, the painful process of defining a new, cheaper structure for the three universities appeared to have come to an end when a restructuring plan was approved by Berlin's parliament. This plan would have cut costs by DM130 million a year by 2003 - at present the annual bill for universities is around DM4 billion, including building and equipment - by reducing total student numbers by 15,000 to 100,000 , with a corresponding reduction in staff. The reduction would be achieved primarily by merging departments and faculties.

In March, however, the universities were told by the city's finance ministry that they would have to reduce their costs by a further
DM135 million over the same period because of the city's unexpectedly severe financial crisis.

Manfred Erhardt, Berlin's research minister, tried to call the Berlin senate's bluff. He wrote to the senate explaining that such radical cuts could be achieved only by closing whole faculties - he mentioned biology and veterinary medicine - and reducing student numbers still further, possibly by an additional 10,000 . He explained that he needed to be sure before he took any steps that the senate would take political responsibility for such drastic moves.

When the contents of the letter became public, there was uproar. As a result, the senate's finance committee offered a compromise, based on a proposal from a recently established Parliamentary working group comprising Erhardt and the science spokesmen from the two main coalition parties: CDU spokesman Eberhard Engler, from the Max Delbruck Centre for Molecular Medicine and SPD spokesman Bert Flemming, a physiologist from the Humboldt university.

Engler and Flemming had argued that a less adversarial mechanism should be set up to identify how cuts could be made. This would be made by a committee made up of four politicians (representing both science and finance committees), four representatives from the universities, and Erhardt.

Erhardt says he is not convinced that the committee will work because it is likely to find it difficult to reach a consensus. But he welcomed the decision that there will be no further reduction in student numbers.

The committee will discuss what further savings the universities can make that will be acceptable to all parties. But its decisions will not be made until autumn at the very earliest. Jealousies are being stirred up between the three competing universities. The Free University, for example, resents the large amounts of money spent on being spent on refurbishing the dilapidated Humboldt University. The Humboldt in turn defends its investment programme on the grounds that it needs to be able to compete with the Free University on equal terms.

Furthermore, all three universities are unhappy that they are being asked to bear the full burden of Berlin's cuts in its science budget, while non-university research establishments are being left untouched.

Erhardt claims that this is because Berlin pays the full cost of its universities, whereas the federal government pays a fixed proportion of the costs of the research establishment, and that this money would be lost to the city if it made its own support for these.

Alison Abbott

\section{Space station critics vow to maintain fight against project}

Washington. Opponents of the United States' international space station, having decisively failed in this year's attempt to kill the project in Congress (see Nature 370, 3; 1994), remain confident that it will succumb in 1996 or 1997 , when the federal budget will be even tighter.

"This year's budget is going look like a picnic compared with 1996, 1997 and 1998," says Tim Roemer (Democrat, Indiana) who moved the unsuccessful amendment in the House of Representatives to kill the station. There is a widespread feeling that a legally imposed cap on overall discretionary spending means that far larger cuts will be required in those years.

The relatively large amount of room for manoeuvre present in this year's budget was graphically demonstrated last week when the Senate budget bill, which includes spending by the National Aeronautics and Space Administration (NASA) and the National Science Foundation (NSF) was voted on in committee.

The Senate Veterans Affairs, Housing and Urban Development and independent agencies(VA-HUD) appropriations subcommittee, chaired by Barbara Mikulski (Democrat, Maryland), proposed budgets for NASA ( $\$ 14.4$ billion) and NSF ( $\$ 3.45$ billion) that are substantially above the president's requested level.

These budgets, which are likely to be approved by the full Senate, follow bartering between Mikulski and the White House, in the process of which she extracted an impressive list of concessions in exchange for her strong support of the space station.

The extra money has become available because the White House accepted adjustments in the housing budget that will relieve pressure on the rest of Mikulski's turf. The extra NSF money - $\$ 300$ million, compared to $\$ 55$ million requested — will be for construction of new laboratories and facilities, while NASA will get $\$ 400$ million that it had not requested to start building $\$ 2.5$ billion worth of wind tunnels.

The latter are immensely popular in Washington, as they are intended to help Boeing to compete with the European Airbus. Anyone suggesting that Boeing would be better off with a small wind tunnel and some computer simulation software does not understand how Congress works. Both Senate proposals have still to be agreed in conference with the House, but Senate staff say they now have the administration's support and are therefore likely to prevail.

Meanwhile Roemer is promising to subject NASA to ever-tighter scrutiny on the space station. He has inserted a provision in a House NASA authorization bill requiring 